\title{
ROLE OF ISLAM AND ITS TOLERANCE IN CONSTRAINING TERROR
}

\author{
Mohamed Omar Moftah Medon and Ali Mohamed Ane6a \\ Islamic Science University of Malaysia. Telp.+60172320846. \\ email: Medon_m@yahoo.com
}

\begin{abstract}
Abstrak
Toleransi dalam Islam muncul dari dua sumber syariah, primer dan sekunder (al Quran dan Hadits). Banyak sekali bukti yang ditemukan dalam sumber utama Syariah tersebut yang menyuruh manusia untuk berlaku toleransi dan menghindari teror. Al Quran dan as Sunnah itu sendiri merupakan sumbersumber utama syariah yang menyerukan toleransi dan kebaikan dan tidak adanya sikap ekstremisme dalam Islam. Islam tidak mengenal perbedaan di antara sesama manusia, melainkan kualitas takwanya. Demikin juga tidak ada perbedaan antara orang Arab dan bukan. Oleh karena itu, sumber-sumber utama Islam tidak memiliki hubungan apapun dengan tindak teror dan pembunuhan terhadap orang-orang yang tidak bersalah. Karena ekstrimisme semisal pembunuhan terhadap orang-orang yang tidak bersalah, dilakukan dengan tindakan teror, sementara toleransi dalam Islam bersumber dari syariat Islam yang tidak menerima tindak terorisme.
\end{abstract}

The tolerance in Islam springs from sharia in both its primary and secondary sources. There are abundance evidences found in the Quran and sunnah which order people to tolerate and avoid terror. Quran and Sunnah as a primary sources of sharia do not accept terror, but invite people to have a sense of tolerance and kindness and non-extremism in Islamic dealings. Islam unrecognized a differentiation among people, except the quality of their taqwa. That is why there is no different between Arabs and nonArabs. Therefore, the primary sources of Islam have no any relation with terror and killing of the innocent. Such an example, killing the innocent is done toward a certain direction, side, group, doctrine, political thought, or sect that are the reasons of terror and enmity which increase force within communities.

Kata kunci: toleransi, Islam, syariah, terorisme 


\section{Introduction}

Moslems live a new phase in its history stands on a multiway road needs the help of its scholars, thinkers and decision-makers to amend its past mistakes, reform its present and light its future. In this critical phase, our ummah and its belief are under high pressures that could eradicate it if it is not for its strong religion and the support of its Lord, Allah SWT. When we look at the depth of the principle of easiness and tolerance in the religion of Allah SWT, we find ourselves a head of a rich sea of evidence, texts and events that confirms such principle and urges Muslims to adopt it and follow it.

Therefore, we will talk about this great Islamic principle by introducing some of the aspects through which such principle shows clearly and succinctly as far as possible.

The concept of samaha or tolerance, is determined by knowing its linguistic meaning where Ibnu Faris in his dictionary Measures of Language shows that al seen, (sa), al meem, ( $\mathrm{ma})$, and al ha (ha), are corrects root indicating fluency and simplicity (Ibnu Faris, 1402 H: 99), it also indicates forgiveness and flexibility (al Zawi and Tinaji, 1383: 39), and in the Hadist, the Prophet said: "Allah SWT likes most the peaceful religion" (QS al Bukhari, part 2: 9).

In this, also Allah SWT says: "Invite (all) to the way of Thy Lord with wisdom and preaching; and argue with them In ways that are best and Most gracious: for Thy knoweth best, who have strayed from His path, and who receive guidance (QS An Nahl;16)"

Allah SWT shows to His Prophet the right way which the way of wisdom, nice advice, and nice debate, for the basis of da'wah, Call of Islam, is the nice talk even if the person who is called is the most unjust person. Allah SWT says to Moses and Haroon when sent to Pharaoh:"But speak to Him mildly; Perchance He may take warning or fear ((Allah))." (QS Thaaha: 44).

Therefore, the nice manners and the Call with kind and nice talk have the best results.

\section{Tolerance of Islam Da'wah}

Allah SWT has ordained the religion of Islam as a mercy for humanity; and such mercy is general as the Quran states: "We have sent you (Muhammad SAW) not but as a mercy for the Alamin (jin, mankind and all that exists) (107)" (22), and he also said in Surah Ibrahim:

"Alif Lam Ra (this is) a Book which we have revealed unto thee, In order that Thou mightest lead Mankind out of the depths of darkness into light - by the leave of their Lord - to the way of (Him) the Exalted In power, worthy of all praise!" (QS Ibrahim: 1)" 
The others of such ayat of Quran which clearly state that Islam is the religion of mercy and forgiveness and that it is the religion from which the logical solution is sought: from the darkness and pagan sins to the luminous light which lightens, for its follower, what he needs in all aspects of his religious and public life. With all the qualities it has and the pillars it stands upon, Islam is the religion of easiness and tolerance, for in which Allah SWT has taken into consideration what the souls are created in need for; its obligations are never in excess to their abilities. The most valuable aspect of its continuation and commonality for all humanity is renouncing the prohibitions (chains) that have been imposed upon sons of Izrael in punishment for their injustice and atrocities as the Quran states:

"Those who follow the apostle, the unlettered Prophet, whom They find mentioned In their own (scriptures),- In the law and the Gospel;-for He commands them what is just and forbids them what is evil; He allows them As lawful what is good (and pure) and prohibits them from what is bad (and impure); He releases them from their heavy burdens and from the yokes that are upon them. so it is those who believe In him, honour him, help him, and follow the light which is sent down with him,-it is They who will prosper" (QS Al A'raf:157)

The tolerance in Islam springs from the Sharia in both its primary and secondary sources. Much evidence is in abundance in the Quran and Sunnah. Allah SWT says:

"And (Allah) ahs not laid upon you in religion any hardship: it is the religion of your father Ibrahim. It is He (Allah) who has named you Muslims both before and in this (the Quran) that the Messenger (Muhammad SAW) may be a witness over you and you be witnesses upon mankind! So perform as-Salat, give Zakat and hold fast to Allah. He is your Maula (Patron, Lord), what an excellent Maula and what an excellent Helper" (QS Al Hajj: 78).

The follower of the major parts of Sharia and even their smaller parts can find out that easiness is there in worship aspects more than any other aspects; this is a normal matter that does not require from an observer but knowing that worship is a total relation between a man and his Lord. Allah SWT is kind with His creatures. Therefore, such relation is based on easiness and tolerance, that is, non-burden. The Islamic Sharia is peaceful. Evidence for Muslim tolerance, while dealing with others, is in abundance whether in the home land of Islam or in the other places conquered by Muslims (al Ghazali, 1409H: 9).

Islam has urged for just dealings with non-Muslims; Allah SWT says: "Allah forbids you not, with regard to those who Fight you not for (your) Faith 
nor drive you out of your homes, from dealing kindly and justly with them: for Allah loveth those who are just" (QS Al Mumtahanah: 8).

And this is a principle in connection with the Principle of Justice in Islam, for it connects with the Islamic principles and values: They have what we have, and upon them is what is upon us. No one is more just than the one who makes you equal to him in justice, judgment and power. Muslims never force anyone to accept Islam, rather they have left them along with many others practicing their religious rituals in their religious places: the Churchesand synagogues. Rather, Muslims have protected and defended them; Muslims have cared for the non-muslim religious scholars, old people, women and children. What show the tolerance of Islam are many, for instance, the Prophet Muhammad SAW said: "I have been sent with the peaceful religion" (Muslim, no. 2009).

Moreover, Omer Ibnu al Khattab, ordered the Jizyah, tax, to be removed from a man of Ahl al Kitab, a man of the people of the Scripture, and be replaced by a fixed amount of money to be given to him from the Muslim House of Money; he said to him his famous word: we have not done justice with you: we have taken from you when you were a youth and lost you when you were old. He also ordered that his children be given from the House of Money. Islam is a religion of easiness, tolerance and flexibility. The most prominent aspects of tolerance in Islam appear within the field of $d a^{\prime}$ wah, spread of religion and dealing with the sinners and those of other views. Most of the westerners and those who did not read the Quran cannot understand the misunderstandings in their talk about Islam in that it is, in their opinion, a religion which does not know tolerance. Yet, there are those who did justice with Islam; and among those latter ones are the following: Abfitshon says: it is saddening that the Christian nations have to learn the religious tolerance from Islam"

The Historian Ernest Metro says: "Salah al Deen was loved in the west due to his being a gentleman, for his generosity after seizing Jerusalem and for having a different conduct than that of the Crusaders something that aroused their curiosity and admiration; he was also very tolerant and is famous for it (Al Saghir, 1424H: 21).

The Prophet's tolerance has not been only with muslims but it was also with the people of the Scripture and the pagans during war. He (Muhammad SAW) has asked his companions to take good care of Copts; it has been 
confirmed that he (Muhammad SAW) said: if you conquered Egypt, take good care of Copts, as they have a covenant and relation with us (Corrected by al Hakem, al Thahabi in his Mustadrak and al Albani in his Correct Series, Hadith no. 1374), also in Sahih Muslim:

"You will conquer a land in which al Qirat is mentioned; take good care of its people, for they have a covenant and relation with us. Ernest Renan says in his book Life of Jesus: "Christianity did not know religious tolerance".

Lion says muslims have left people free in their religious matters; they have protected the Roman Archbishops and the Latin Metrans who had security as Omer Ibnu al Khattab secured people's wealth and religion after his entrance to the Quds city. The fact is that nations did not know kind and tolerant conquers like Arabs, such mercy was a reason for the embrace of Islam by many nations.

Thomas Arnold says: "The Christian Church has gotten stronger and progressed within the Muslim care and rule, and all the Christian beliefs have enjoyed good care and tolerance from the muslims rulers alike who also prevented the persecution of Christians from other Christians" (al Jirain, 1988: 87).

The Prophet (Muhammad SAW) forgave Abdullah IbnuThi al Khuwaiserah al Tamimi: while the Prophet (Muhammad SAW) was dividing, he told the Prophet: be just oh Messenger of Allah, he said:

"What! Who can be just if I do not be just? Omer Ibnu al Khattab said (to the Prophet): let me cut his head! He said, leave him; he has fellows, a prayer of one of you are nothing compared to their prayers, and his fasting is nothing compared to their fasting; they go out of religion as an arrow goes out of its bow; he looks at his arrows, he finds nothing" (Bukhari, no. 6933).

It is the utmost end of tolerance, for the Messenger of Allah (Muhammad SAW) did not punish but forgave him. The Prophet (Muhammad SAW) has other situations with the pagans. Even in war, the tolerance of the Prophet (Muhammad SAW) was there; he told them: He who enters the house of Abu Sufyan is safe, he who closes his door upon himself is safe; and who dropped his weapon is safe (Sahih Muslim, no. 178).

This confirms that Islam is the religion of tolerance and removes horror, force and terror from Islam in a time when Islam was strong and never weak in need of flattering or begging those who held opposing views. Islam was independent, deciding for itself without any fear of enemies. Muhammad 
SAW was not in threat of killing, rather he was the maker of events as he was paving the pillars of his state and Calling to Islam with insight and guidance. The one who is familiar with the ayat of Surah al Baqarah finds it having a lot of Sharia laws concerning the personal affairs, the civil and legal relationships and the international relations, as it regulates the civil community affairs due to its being the longest surah in the Quran (Abu Zahrah: 19).

Regarding the ayat of Quran that urges for Jihad against disbelievers, Islam has shown the way of da'wah to Islam in this ayah:

"Invite (all) to the way of Thy Lord with wisdom and preaching; and argue with them In ways that are best and Most gracious: for Thy knoweth best, who have strayed from His path, and who receive guidance" (QS An Nahl: 125).

As observed above, Islam never stands on persecution of those who held opposing views to it, confiscating their property, forcing them to change their beliefs, or unjustly touching their wealth, dignity or blood. In this regard, the history of Islam is the whitest history on earth. Moreover, Islam has spread with its power on souls, its peaceful teachings, faith and human values that it has. It has reached to faraway places peacefully as it is the matter with India, Malay Archipelago, Indonesia and others by the course of wisdom, nice dealing with the non-Muslims via trade relations which were a civilized expression of the Islamic model in human and international relations. An observer to the extent of the peaceful spread of Islam to such places finds that the percentage of Muslims in them is higher than the other places that Islam has reached to as a result of Islamic Conquests due to the latter places' government resistance to Islam as well as non chance of introducing of Islam and knowing its life and faith principles.

\section{No Contradiction Between Jihad and Tolerance of Islam}

Fight, in Islam, has been ordained to fight back the conspiracy of pagans. For after Islam has established the freedom of belief, it obliged no one to embrace it without a desire or will of oneself; Allah (SWT) says: "Let there be no compulsion In religion: truth stands out Clear from error: Whoever rejects evil and believes in Allah hath grasped the Most trustworthy hand-hold, that never breaks. and Allah heareth and knoweth all things "(QS Al Baqarah: 256).

Many other ayat of Quran establish this principle (the freedom of belief). Here, the relation is based on tolerance, justice and easiness. Fight has been ordained only when a group of disbelievers decide to attack Islam and its followers and against its spread (Haikal, 1996: 583-604). If they got prepared 
to do so or started it, they must be warned or else they must be fought by all possible means; Allah SWT says:

"And Fight them on until there is no more tumult or oppression, and there prevail justice and Faith In Allah. but if They cease, let there be no hostility except to those who practise oppression" (QS Al Baqarah:193).

Allah SWT says emphasizing, from the beginning, the renouncing of dzulm or injustice, and transgression: "Fight In the cause of Allah those who Fight you, but do not transgress limits; for Allah loveth not transgressors." (QS Al Baqarah: 190)

This is what makes fight and force obligatory in Islam with the pagans, for fight in Islam never be but after all the possible peaceful means are exhausted with those holding opposing views. The tolerance of Islam is also seen in dealing with the sinners and those holding opposing views to Muslims. The Prophet Muhammad SAW showed that sins are with levels; each sinner is treated based upon his sin, for if all are treated as disbelievers, with threat, force, beating or not dealing with them, then this will cause them to abandon this religion, to go away from the Prophet Muhammad SAW and from the da'wah of Islam, and then they fall in sins as it is a nature in people. Abu Hurairah r.a said that the Prophet Muhammad SAW said: "If you do not sin, Allah will take you and replace you with people who could make sins and then they seek forgiveness and Allah will forgive them" (Muslim, no. 2106).

Putting people in embarrassing situations is not an aspect of Sharia; rather it is easiness that is an aspect of Sharia. There is much evidence regarding this, among which is what follows. Allah SWT says:

"It is part of the Mercy of Allah that Thou dost Deal gently with them Wert Thou severe or harsh-hearted, They would have broken away from about thee: so pass over (Their faults), and ask for ((Allah)'s) forgiveness for them; and consult them In affairs (of moment). then, when Thou hast taken a decision put Thy trust In Allah. for Allah loves those who put their trust (in Him)" (QS Al Imran: 159).

Allah SWT also says: "......And (Allah) has not laid upon you in religion any hardship" (QS Al Hajj: 78).

A young sinner and the mistaken cannot be reformed by forcing him or considering him as a disbeliever, rather it is by calling him to tawbah (repentance) and rectifying his course, showing him the mistake he has made; all this is evidence that Islam's tolerance is a basic principle and a prominent feature of Islam. The embrace of Islam by many people without compulsion is a result of such tolerance. The Quran calls for freedom of belief and does not 
oblige people of embracing It. It makes calling people to Islam an obligation upon Muslims who should present its principles to people. Each person has the right to choose Islam or any other religion by his own freedom, without any imposition of any sort whether from Islam, Christianity, Judaism or any other. We ask: had the Prophet Muhammad SAW obliged the pagan of Quraish to embrace Islam upon his conquer of Mecca, and after all lands and people were under his control, when Islam was at the pinnacle of its power and victory when the Prophet Muhammad SAW said: "never mind, go, you are free" (al Baihaqi, no. 16809).

\section{Conclussion}

Jihad has been called upon for protection of freedom of belief against aggressors and the Fitnah in religion from those who have weak of faith and against the attack on the land of Islam. The wars of the Prophet Muhammad SAW, upon reading history, indicate that he (Muhammad SAW) did not fight those who held different religions but in two matters: either a former attack had been occurred from the part of the pagans or due to some rulers preventing the Prophet Muhammad SAW and Muslims from spreading Islam and their attempt to make fitnah to revert muslims from their religion. From what we have presented above, we see that the word "jihad" in Islamic sources has a general meaning: resisting the enemy, resisting the self or making the good and rejecting the evil. Muslim scholars have defined jihad, in its specific meaning, as doing the best and energy in fighting in Allah's Path with one's self, money, tongue with the aim of supporting Islam and muslims, fighting for preventing the aggressors or an aggression and obliging them to go away from the land of muslims, or fighting in defense of one's self, money and dignity as this is also considered a Jihad in Allah's Path. The Islamic Sharia has prohibited aggression while Jihad such as no killing of women, old people, religious people devoting themselves for worship, and the civilians who do not fight with the aggressors. It has also prohibited getting in excess in killing, killing for spreading corruption in earth, taking peoples' wealth or damaging plants and fruits.

\section{Results and Recommendations}

Islam has never persecuted its opponents, confiscating their property, forcing them to change their beliefs, or unjustly touching their wealth, dignity or blood.In this regard, the history of Islam is the whitest history on earth. The 
primary sources of Sharia do not accept terror, for the Quran and Sunnah are themselves those primary sources of Sharia, calling for tolerance and kindness and non-extremism in Islamic dealings; and this is the ideal aim and means of Islam-something that makes taqwa' the basics of differentiation in Islam between the Arabs and non-Arabs.

Islam has spread with its power on souls, its peaceful teachings, faith and human values that it has. It has reached to faraway places peacefully as it is the matter with India, Malay Archipelago, Indonesia and others by the course of wisdom, nice dealing with the non-muslims.

The Quran calls for freedom of belief and does not oblige people of embracing religions. Each person has the right to choose Islam or any other religion by his own freedom, without any imposition of any sort whether from Islam, Christianity, Judaism or any other.

Jihad has been called upon for protection of freedom of belief against aggressors and the fitnah in religion and against the attack on the land of Islam. The wars of the Prophet Muhammad SAW, upon reading history, indicate that he (Muhammad SAW) did not fight those who held different religions but in two matters: either an attack had been occurred from the part of the pagans or due to some rulers preventing the Prophet Muhammad SAW and Muslims from spreading Islam and their attempt to make Fitnah to revert Muslims from their religion. Islamic Sharia has prohibited aggression while Jihad such as no killing of women, old people, religious people devoting themselves for worship, and the civilians who do not fight.

\section{References}

As Sunnah Muhammad SAW

Al Quran al Karim

Abu Zahrah, Muhammad...- International Relations in Islam. Dar al Fikr al Arabi, Egypt.

Al Baihaqi, Imam Hafiz Abu Bakr Ahmed Ibnu al Hussein Ibnu Ali. 458 H. al Sunan al Kubra, supplemented by al Jawhar al Naqi. $1^{\text {st }}$ ed. $1354 \mathrm{H}$. Dar al Ma'refah, Lebanon, Beirut.

Al Bukhari, Abu Abdullah Muhammad Ibnu Ismael Ibnu Ibrahim Ibnu al Mughirah. 256 H. Sahih al Bukhari. Al Makniz Islamic Society. 1421 H. Dar IbnuKhathir, al Yamamah, Beirut. 
Al Ghazali, Muhammad. 1490 H. Extremism and Tolerance between Christianity and Islam. $1^{\text {st }} \mathrm{ed}$. Dar al Tawzi', Cairo.

Al Jabrain, Saad Abdul Rahman. 1988. International Terror: Perspective and Method of the Islamic Sharia in Confronting it. MA Thesis. Naif Academia for General Security Sciences,Saudia Arabia, Riyadh.

Al Saghir, FalehIbnu Muhammad IbnuFaleh al Saghir. 1424 H. Easiness and Tolerance. Faculty of Islamic Principles, Damma University, Riyadh.

Al Zawi, Tahir Ahmed, and Tinaji, Mahmoud. 1383 H. Ibnu al Athir. $1^{\text {st }}$ ed. Dar Ihya' al Kutub al Arabiya, Beirut.

Haikal, Muhammad Khair. 1996. Jihad and Fight in Legal Politics. 1417H. Dar al Bayariq, Beirut.

Ibnu Faris. 1402 H. Dictionary of Measures of Language. $3^{\text {rd }}$ ed. Al Khaniji Library, Egypt.

Muslim, Abu al Hassan Muslim Ibnu al Hajaj al Qushairi al Nisabori. $261 \mathrm{H}$ SahihMuslim: Book of Bir, Silah, and Adab: checked by Muhammad Fuad Abd al Baqi.1403H; 1983. Dar al Fikr al Arabi, Beirut. 